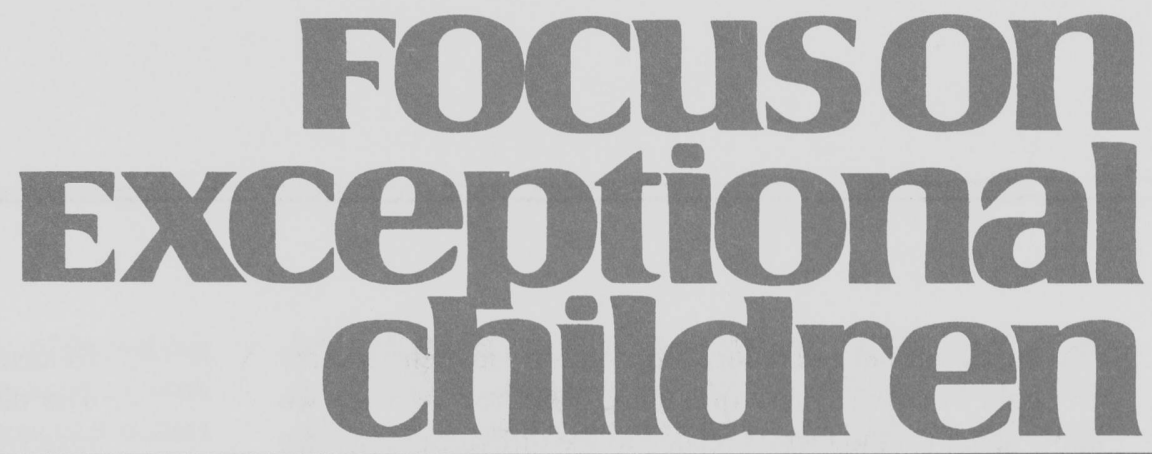

\title{
Supporting Beginning Special Education Teachers
}

\author{
Susan D. Whitaker
}

The first few years of teaching are indeed vital ones. During these years the novice emerges from the status of a student responsible for his or her own learning to that of a teacher responsible for promoting learning in others (Cooke \& Pang, 1991). Tonnsen and Patterson (1992) described the first year this way:

\begin{abstract}
New teachers aren't always prepared for the challenges they'll find in the profession. They enter the field expecting-and often being expected-to do what the veteran teacher has been doing for years, with equal success. They face long days, filled with little time for reflection and planning. They face children with problems they can't understand. They face a bureaucracy that forces them to teach a prescribed curriculum in a prescribed manner . . Just months earlier, most of these new teachers were carefree college students, idealistic to a fault. If they're thrown into a classroom and expected to succeed with little or no support, it's no wonder many of them quickly become disillusioned. (p. 29)
\end{abstract}

And it is no wonder that so many teachers leave the field early in their careers. Add to this description an ill-equipped classroom, limited materials and supplies, overwhelming amounts of paperwork, a myriad of legal and accountability issues, students of widely differing abilities, and students with serious emotional and behavioral problems, and you have the situation facing many beginning special education teachers. Thus the stage is set for a beginning year that will severely test the morale and dedication of even the most well prepared and enthusiastic new teacher.

An estimated $25 \%$ of beginning teachers do not teach more than 2 years and $40-50 \%$ leave the teaching profession within the first 5 years of teaching (Harris \& Associates, 1992; Huling-Austin, 1986; Kirby \& Grissmer, 1993; Schlechty \& Vance, 1983). By the end of 5 years, $43 \%$ of the special educators newly hired in Michigan and North Carolina were no longer teaching in those states (Singer, 1992). Although some of these teachers may have been teaching in other states and others may ultimately have returned to the profession, even the temporary loss of these teachers is significant. And far too many leave permanently. The Council for Exceptional Children's (2000) report "Bright Futures for Exceptional Learners" states that "four out of every ten special educators entering the field leave special education before their fifth year of teaching" (pg. 1).

Why does this happen to teachers who begin with such enthusiasm and so many high hopes? What are the needs and concerns of beginning special education teachers? What kinds of supports can we provide to these beginning teachers that will ease their transition

Susan Whitaker is the Director of Special Education for Spartanburg County School District No. 7 and an adjunct professor at Converse College, Spartanburg, South Carolina. 
into the classroom and reduce attrition early in their careers? To begin to answer these questions, I will review what we know about (a) the factors related to the difficulties teachers experience in their first year of teaching, (b) the needs and concerns of beginning teachers, (c) the needs and concerns of beginning special education teachers, and (d) induction and mentoring as supports for beginning teachers. I will conclude with recommendations for ways that various individuals can support beginning special education teachers.

\section{FACTORS RELATED TO THE DIFFICULTIES EXPERIENCED IN THE FIRST YEAR}

A review of the literature indicates that five factors are related to the difficulties many teachers face in their first year or years of teaching:

1. An inability to transfer learning from theory into practice

2. A lack of preparation for many of the difficulties and demands of teaching

\section{FOCuson Exceptional children}

ISSN 0015-511X FOCUS ON EXCEPTIONAL CHILDREN (USPS 203-360) is published monthly except June, July, and August as a service to teachers, special educators, curriculum specialists, administrators, and those concerned with the special education of exceptional children. This publication is annotated and indexed by the ERIC Clearinghouse on Handicapped and Gifted children for publication in the monthly Current Index to Journals in Education (CIJE) and the quarterly index, Exceptional Children Education Resources (ECER). The full text of Focus on Exceptional Children is also available in the electronic versions of the Education Index. It is also available in microfilm from Xerox University Microfilms, Ann Arbor, MI. Subscription rates: Individual, \$36 per year; institutions, $\$ 48$ per year. Copyright (c) 2001, Love Publishing Company. All rights reserved. Reproduction in whole or part without written permission is prohibited. Printed in the United States of America. Periodical postage is paid at Denver, Colorado. POSTMASTER: Send address changes to:

$$
\begin{gathered}
\text { Love Publishing Company } \\
\text { Executive and Editorial Office } \\
\text { P.O. Box } 22353 \\
\text { Denver, Colorado } 80222 \\
\text { Telephone (303) 221-7333 }
\end{gathered}
$$

Karen Harris

University of Maryland
Thomas Skrtic University of Kansas

James Shriner University of Illinois

Erica J. Lawrence Editor
Stanley F. Love Publisher
3. Reluctance to ask questions or seek help

4. The difficulty of the teaching assignment and the inadequate resources provided

5. Unrealistic expectations and the associated loss of a sense of efficacy.

These factors significantly impact the needs and concerns of the novice teachers as they begin their teaching careers.

\section{Inability to Transfer Learning From Theory into Practice}

Many studies reveal that the novice teacher does not transfer what he or she knows on a theoretical basis from the preservice level to what is actually done on a practical daily basis in the public school classroom (Corcoran, 1981; Ryan, 1992). These teachers are confronted with unknown students and staff members, an unknown curriculum, unknown policies and procedures, and unfamiliar norms and rituals. This condition of "not knowing" results in data overload and can send beginning teachers into a state of shock in which they are unable to transfer the skills and concepts they mastered in the college setting into the public school classroom.

\section{Lack of Preparation for the Demands of Teaching}

This reality shock seems to stem, in part, from a lack of preparation for many of the difficulties and demands of teaching (Gaede, 1978; Gordon, 1991; Moran, 1990). In this regard, Gaede (1978) surveyed 272 teachers with a range of actual teaching experience. He measured self-assessed professional knowledge on a 5-point Likert scale. The results suggested a rise in self-assessed knowledge at every level except at the end of the first year of teaching, when the level actually drops. Gaede concluded, "Teachers discover during actual teaching that they were not as well prepared as they thought they were" (p. 407).

When difficulties arise for these teachers, it usually comes as a surprise (Ryan, 1992). Because they have spent 7 hours per day, 5 days per week, for 36 weeks a year since age 5 in a school setting, they tend to feel that they are on safe and familiar ground. But the reality is that even though the setting may be familiar, they have viewed it only from the perspective of the student. Now they must transfer to the teacher's perspective and into the teacher role. They must take the skills and knowledge they learned in a general way in the university setting and apply these in a specific context in their own classrooms.

\section{Reluctance to Ask Questions or Seek Help}

This problem is further complicated by the beginning teacher's need to appear both confident and competent 
(Corcoran, 1981). In his now classic study of beginning teachers, Lortie (1975) found that beginning teachers seek help infrequently. He also found that experienced teachers refrain from offering unsolicited advice. Glidewell, Tucker, Todt, and Cox (1983) confirmed these findings. In their study of 121 teachers, they found that $92 \%$ of novice teachers did not seek help from their colleagues except to swap stories about personal experiences. This lack of support leads to a profound sense of emotional, social, and professional isolation in which the beginning teacher is afraid to ask for help for fear of appearing incompetent, and the experienced teacher is afraid to offer help for fear of interfering.

\section{Difficulty of the Initial Teaching Assignment And Inadequate Resources}

Another challenge that novice teachers face is the difficulty of the initial teaching assignment and the inadequate resources they are often given (National Association of State Boards of Education, 2000). Rather than increasing the beginning teacher's responsibilities gradually over time, beginners are often given more responsibilities, the least desirable courses, the most time-consuming and least rewarding assignments, extracurricular duties the experienced teachers are unwilling to accept, and the most difficult students (Gordon, 1991).

The available jobs are often the ones that the experienced teachers do not want. "In most professions, the challenge of the job increases over time as one acquires experience and expertise. In teaching, we've had it reversed. Typically, the most challenging situation a teacher experienced was in his or her first year" (Glickman, 1990, p. vii).

\section{Unrealistic Expectations and the Loss of the Sense of Efficacy}

These challenges often leave the novice teacher believing by the end of the first year of teaching that he or she cannot teach effectively. At that time, the teacher either leaves the profession or becomes resigned to simply going through the motions (McLaughlin, Pfeifer, Swanson-Owens, \& Yee, 1986). A teacher's sense of efficacy (the belief that teaching can influence student learning and that they themselves are competent teachers) is one of the few variables consistently found to be positively related to student achievement (Woolfolk, Rusoff, \& Hoy, 1990). For this reason, the novice teacher's loss of the sense of efficacy is of serious concern for the personal well-being of the teacher and also for the academic achievement of the students.

Sadly, the Metropolitan Life Survey (Harris \& Associates, 1991) reported that after one year of teaching, only
$68 \%$ of the teachers strongly agreed that they can really make a difference in the lives of their students. This finding represents a significant decrease from the $83 \%$ who strongly agreed with the statement before beginning their first year of teaching.

Weinstein (1988) examined the expectations of 118 students enrolled in the elementary teacher education program at the University of Arizona. She developed a 33-item questionnaire based on Veenman's (1984) list of the most frequently perceived problems of first-year teachers. The prospective teachers were asked to rate how much of a problem they thought the average first-year teacher has with each item, and then how much of a problem they thought they would have with each item. The mean optimism values were all statistically significant (all but one beyond the .0001 level), indicating a significant tendency for the prospective teachers to expect the tasks of teaching to be less problematic for themselves than for most first-year teachers. Although this study used a restricted sample, Weinstein concluded, "The present results support the argument that unrealistic expectations contribute to the reality shock experienced by many beginning teachers" (p. 39).

Novice teachers enter teaching with a strong service ethic and dedication to helping students. When they no longer believe they can effectively accomplish these goals, they feel frustration and a sense of failure. This loss of a sense of efficacy results in severe disillusionment during the first year of teaching.

\section{Needs and Concerns of Beginning Teachers}

A number of studies have examined the needs and concerns of first-year teachers. In a comprehensive study, Veenman (1984) rank-ordered the problems identified in the research literature as the primary problems of beginning teachers at that time. Table 1 identifies the 24 most frequently perceived problems of beginning teachers from that study. Dollase (1992) surveyed beginning teachers regarding their perceptions of the severity of the problems on Veenman's list in today's classroom (rated on a 5-point Likert scale). Table 1 summarizes the results of this study as well.

Results of the two studies are quite similar in that eight of the top 12 problems are the same in both lists. Motivating students and dealing with individual differences were ranked second and third in Veenman's study and ranked third and second in Dollase's study. A striking difference, however, is that lack of spare time is ranked first in the Dollase study and 22nd in the Veenman study. Another notable difference is that in the Dollase study, problems related to individual students, such as dealing with problems of individual differences, dealing with slow learners, dealing with 
TABLE 1

Comparison of Most Frequently Perceived Problems of Beginning Teachers

\section{Problem} Veenman's (1984) Rank Order Dollase's (1992) Rank Order

Classroom discipline 1

Motivating students

Dealing with individual differences

Assessing students' work

Relations with parents

Organization of class work, time, and activities

Insufficient materials and supplies

Dealing with problems of individual students

Heavy teaching load resulting in insufficient preparation time

Relations with colleagues

Planning of lessons and school days

Effective use of different teaching methods

Awareness of school policies and rules

Determining learning level of students

Knowledge of subject matter

Burden of clerical work

Relations with principals/administrators

Inadequate school equipment

Dealing with slow learners

Dealing with students of different cultures and deprived backgrounds

Effective use of textbooks and curriculum guides

Lack of spare time

Inadequate guidance and support

Large class size

$\begin{array}{lr}1 & 6 \\ 2 & 3 \\ 3 & 2 \\ 4 \text { (tie) } & 16 \\ 4 \text { (tie) } & 19 \\ 6 \text { (tie) } & 11 \\ 6 \text { (tie) } & 9 \\ 8 & 5\end{array}$

928

$10 \quad 23$

$11 \quad 18$

1210

$13 \quad 20$

$14+7$

16 (tie) 16

16 (tie) 12

16 (tie) 24

$18 \quad 21$

194

$20 \quad 14$

$21+13$

$22-1$

$23 \quad 17$

$24 \quad 22$

students of different cultures and backgrounds, and determining the learning level of students, are ranked higher than in the Veenman study.

Issues of management such as classroom discipline and organization of classwork, class time, and activities are ranked higher in the Veenman study. These differences may be attributable in part to the fact that the Dollase study is more current or that Veenman reported the frequency of occurrence of the problem in the literature and Dollase examined the perceived severity of the problem. Also, approximately one-third of the studies that Veenman examined were conducted outside of the United States and may not be representative of the needs and concerns of beginning teachers in the United States.

Huling-Austin and Murphy (1987) surveyed more than 150 beginning teachers in 10 school districts in eight states. The areas in which beginning teachers most frequently reported that they needed assistance were managing discipline, finding time to plan, grade papers, and keep records, motivating students, and dealing with individual differences. Odell's (1986) research identified the following needs (in rank order): (a) ideas about instruction, (b) personal and emotional support, (c) information on resources and materials, (d) information on district policies and procedures, and (e) suggestions regarding classroom management. These findings are similar to those of Veenman and Dollase.

Regardless of the date of the study, the sample used in the study, or the methodology employed in the study, the results have been remarkably consistent. The following 12 needs of first-year teachers consistently emerge, although the rankings vary across studies (Gordon, 1991, p. 5):

- managing the classroom

- acquiring information about the school system

- obtaining instructional materials and resources

- planning, organizing, and managing instruction and other professional responsibilities 
- assessing students and evaluating student progress

- motivating students

- using effective teaching methods

- dealing with individual students' needs, interests, abilities, and problems

- communicating with colleagues, including administrators, supervisors, and other teachers

- communicating with parents

- adjusting to the teaching environment and role

- receiving emotional support.

\section{Needs and Concerns of \\ Beginning Special Education Teachers}

Although all beginning teachers seem to have some of the same needs and concerns, certain additional needs and concerns are specific to beginning special education teachers. Results from a series of focus groups and from a survey of beginning special education teachers in South Carolina indicated that beginning special education teachers needed assistance in the following areas (from greatest reported need to least reported need): system information related to special education, emotional support, system information related to the school, materials, curriculum, and instruction, discipline, interactions with others, and management (Whitaker, 2000b; Whitaker, in press). These teachers reported needing significantly more assistance in each area than they actually received. They reported receiving the most assistance in the area of emotional support. The area in which they reported the largest discrepancy between what they needed and what they received was system information related to special education. Table 2 summarizes the needs of beginning special education teachers.

The studies also examined the types of support that beginning special education teachers said they needed. The teachers reported needing both formal and informal meetings with support teachers to discuss areas of concern and to ask questions. They also reported needing opportunities to observe other teachers and to be observed themselves and to receive feedback from the observations.

Special education teachers reported receiving the most assistance from other special education teachers. They also reported receiving quite a bit of assistance from their assigned mentors and from building administrators. They reported receiving less assistance from general education teachers and from special education administrators (Whitaker, in press). Given the specialized nature of the special education teacher's job and the high need for assistance in areas specific to special education such as system information related to special education and selecting and locating materials, it makes sense that beginning special education teachers would find other special education teachers most helpful. They found their mentors more helpful if the assigned mentors were also special education teachers (Whitaker, 2000a).

The relatively high level of support from school administrators that beginning special education teachers perceive is an encouraging finding given the research indicating the importance of building-level support in job satisfaction and in teacher retention (Billingsley, 1993; Billingsley \& Cross, 1991; Cross \& Billingsley, 1994; Karge \& Freiberg, 1992; Miller, Brownell, \& Smith, 1999). The lower level of support they perceive from special education administrators is unfortunate but is consistent with the research indicating that beginning teachers in general perceive less support from district-level administrators (Billingsley \& Cross, 1991; McKnab, 1983).

Some evidence indicates that beginning special education teachers have somewhat different needs and concerns at different times during their early years of teaching. Cheney, Krajewski, and Combs (1992) studied 42 first-year teachers, nine of whom were special education teachers. Through this study they generated and analyzed microphases of development in the first year of teaching.

During the first microphase, called "order and time-filling," special education teachers' needs revolved around scheduling and organizing. "They consistently reported feeling overwhelmed by the demands of IEPs and other procedural matters and by the task of having to work around the schedules of regular classroom teachers and related service providers" (Cheney et al., 1992, p. 20).

During the "timing, planning, and management" microphase the needs of the special education teachers centered on individual students but only the ones who interfered with their ability to conduct lessons. The teachers' concerns still focused on their own self-adequacy. Requests for help from mentors were related to developing and implementing behavior management plans, assessing students using standardized instruments, and communicating with parents and other teachers.

"Experimentation," the next microphase, typically began several months into the school year. In this phase teachers began using more difficult techniques and needed ideas about how to implement these techniques as well as feedback on their effectiveness.

The next microphase typically occurred toward the end of the school year and related to "long-range planning." Here the special education teachers were able to look at and develop goals for an entire school year and begin to plan individually for students. 
TABLE 2

Categories and Subcategories of Assistance Needed by Beginning Special Education Teachers

\begin{tabular}{ll}
\hline Category & Subcategories \\
\hline Forms of & Scheduled meetings: face-to-face contacts \\
Supports/ & formally scheduled between mentor and IYT \\
Assistance & (induction-year teacher)
\end{tabular}

Unscheduled meetings: face-to-face contacts not formally scheduled between mentor and IYT

Observations of First-Year Teacher: classroom observations of IYT by mentor

Observations by First-Year Teacher: classroom observations of the mentor or of other teachers made by IYT

Telephone calls: telephone contacts between the mentor and the IYT

Written communication: notes, letters, e-mail, and other forms of written communication between mentor and IYT

Content of Supports/ Assistance
System information related to the school: giving information about policies, procedures, guidelines, expectations, evaluation procedures (ADEPT), and unwritten rules that pertain to the operation and culture of the school

System information related to special education: giving information about policies, paperwork, procedures, guidelines, and expectations related to the district special education program

Resources/Materials: locating, collecting, disseminating, or selecting materials, equipment, or other resources for use by the teacher

Curriculum/Instruction: providing information about assessment of needs, teaching methods and strategies, curriculum, and evaluation of student progress

Management: giving assistance related to scheduling, planning, organizing, daily routines, and managing the school day

Discipline: providing guidance and ideas related to student behavior

Emotional support: offering support by listening, sharing experiences, and encouraging

Interactions with others: assisting the induction-year teacher in working with parents, colleagues, and administrators
Sample Statements From Beginning Teachers

We need formal scheduled meetings with our mentors at least once or twice a month even if it's only for 30 minutes.

The mentor needs to stop by and check on you periodically and not just wait until you have a question.

I would have been less nervous when I started ADEPT this year if I had been observed by my mentor and gotten feedback.

I would like to be able to observe my mentor also. . I I would like to observe once a month at least.

A lot of times you'll call and you can't get in touch with them [the mentors].

When you have to wait and write down a question and get back to someone, it can be tiresome.

What are the school's expectations? You may be doing something that is out of step with what the procedure is at that particular school. . . In college they don't teach you the unwritten rules.

The most important thing we need help with is paperwork and IEPs. . . . When I did my first IEPs, she sat down with me for the first few I did.

My biggest problem now is materials-what to use. You just don't know enough about materials in your first year.

I need help with my curriculum. Curriculum is very hard because you have to build it yourself.

To me, scheduling was the most difficult and foreign. Nothing prepares you for how to go about doing that.

Behavior management is critical. [Beginning teachers] need help with discipline.

Special ed teachers feel more isolated in schools. We need that personal support.

Mentors need to help us get to know faculty and staff like people in the office do-and how to work with them 
The last microphase typically reached in the first year was the "focus on students." Not all beginning teachers reached this phase, but when they did, they were able to identify and plan for individual student needs. Cheney et al. (1992) concluded, "It seemed that the teachers needed to gain confidence in their own abilities and adequacy as teachers before they were able to shift their focus more fully to students" (p. 23). This is consistent with other findings indicating that the needs of beginning special education teachers seem to be directed first to their own personal needs and then to the mechanics of the job. They reported needing and receiving less assistance in areas directly impacting students, such as curriculum and instruction and discipline (Whitaker, 2000a; Whitaker, in press). This may well be related to the fact that they were simply not ready as first year teachers to focus on those aspects of teaching yet.

The various descriptions of the first-year teaching experience remain remarkably consistent whether they are taken from retrospective accounts of experienced teachers (Lortie, 1975), from journals and interviews with beginning teachers (Ryan, 1992), from ethnographic case studies (Corcoran, 1981; Kuzmic, 1994), or from descriptions of teacher-induction programs (Odell, 1989a). Linda Darling-Hammond (1985) concluded:

\footnotetext{
Teaching is the only profession in which there is so little concern for clients that we are willing to give new practitioners the most difficult and burdensome assignments, leave them without teaching materials, close the door, and tell them to sink or swim on their own. This is not only a disservice to new teachers (half of whom leave within a few years, in part because of this lack of support), but it is also, of course, a tremendous injustice to students. (p. 214)
}

And yet, in their national survey of 1,007 beginning teachers, Harris and Associates (1991) found that, when asked what would have been most beneficial in helping these teachers be more effective in their first year of teaching, 46\% responded that an experienced teacher who was assigned to assist and advise them would have been most beneficial. Harris and Associates further found that both first-year and experienced teachers rank direct and immediate access to advice and assistance as being of the most help in their becoming effective teachers.

\section{INDUCTION AND MENTORING AS SUPPORTS FOR BEGINNING TEACHERS}

Teacher induction with a strong mentoring component is frequently suggested as a means of easing the entry of beginning teachers into the field (Huling-Austin, 1986;
Odell \& Ferraro, 1992; Recruiting New Teachers, 1999). Teacher induction may be defined as "a planned program intended to provide some systematic and sustained assistance, specifically to beginning teachers for at least one school year" (Zeichner as cited in Huling-Austin, 1990b). Huling-Austin (1990b) points out that a beginning teacher program, to be considered an induction program, must provide systematic and sustained assistance and not just a series of orientation meetings or an evaluation process used with the beginning teachers. High-quality induction programs include (a) mentoring relationships between new and experienced teachers, (b) targeted professional development, (c) a focus on at least the first year of teaching, and (d) an evaluation component with planned remediation of weaknesses (National Association of State Boards of Education, 2000).

As explained previously, the very nature of the teaching profession tends to inhibit the induction process. The isolation that most teachers experience and the expectation that the beginning teacher will handle the same job responsibilities as do experienced teachers do not lend themselves to a natural induction process (Glickman, 1990). To be effective, induction must be systematic, planned, and sustained.

Lesley Huling-Austin (1986) identified five implicit and explicit goals of most induction programs:

1. To improve the teaching performance of novice teachers

2. To increase the retention of novice teachers during the induction years

3. To promote the personal and professional well-being of novice teachers

4. To satisfy mandated requirements related to induction and certification

5. To transmit the culture of the system and of the profession.

In addition to these goals of school districts, Hirsh (1990) suggested that it is important to consider the induction goals of the novice teachers. He identified these goals as

1. Deriving personal satisfaction from teaching

2. Developing professional competence

3. Acquiring a sense of community security.

These goals closely parallel the organizational goals identified by Huling-Austin.

The concerns of beginning teachers should be used to identify the types of support to be provided (Odell, 1990). Induction programs must work toward identified goals but remain flexible enough to provide the kinds of 


\section{KAREN'S STORY}

We have a shortage of teachers, especially in special education for many reasons. I, myself, quit early in my career, vowing never to teach again. A year later I found myself back in a classroom for what I thought would be a 1-year stint until I had enough money saved to continue with an alternative plan. But I am still here.

Something I have observed and believe I experienced myself is that the newest, greenest teachers are given the most difficult classes and students to work with. I remember my first teaching job. It was in a Junior High that had sixth through ninth-grade students. My classroom was an old, dilapidated book room with a hodge-podge of books that looked like the dregs or leftovers from previous decades. The paint was peeling off of the walls. I had a full caseload, and the only support I got was from the special education coordinator, who came by to see me sometimes. She was wonderful, but it would have been nice to have a mentor there.

I stayed the second year. The heat to my room had been cut off and an electric heater installed in its place, It sat in my teacher's chair because the electric cord would not stretch to the electric socket if the heater were to be on the floor. The principal decided that I could take over the homeroom and extra duties that his friend, the PE teacher, had been doing. I also had students for whom I was unpreparedsuch as the 17-year-old boy who came to my room to use my stapler before school to staple the fly on his pants. His mom was in jail for murder, and he was pretty much on his own. I was only a few years older than he was.

After that year I left. I had a great year off, ran out of money, and decided to teach another year to save up some money so I could do something else. I fell into a great position teaching in a resource room, loved it, and have been here ever since. I nearly fainted when I was handed my IEPS and I could hold them in my hands instead of needing a big a cardboard box. The IEP was printed on some paper that allowed us to write our IEP once and it would transfer to the other two copies. I thought I had gone to heaven! Even though that year my classroom was a windowless audiovisual room, I was fortunate to work with very supportive people. I am still overworked and underpaid, but I have learned not to take things too seriously. I do not really know what has made the difference. Maybe it was that year off. And maybe it is my situation.

The school is great. I now have a full-sized classroom. I have a computer that is hooked up to the Internet, and a tape player, an overhead projector, a language master, shelves, and a painted and carpeted room. My room has a color television and a VCR. I even get $\$ 400$ each year to buy supplies for my classroom, and 1,000 sheets on the copier each month. I get to do my own scheduling. I can control the thermostat in my room. The room is air-conditioned and heated.

The room has a lovely view of the swamp and giant bamboo forest. Spanish moss drapes the crepe myrtle tree in front of my own private parking space. And my own two children are allowed to attend with me even though they are out of zone. I am within 5 minutes of my home. The teachers here are nice to work with. The principal has a special education background and is supportive. In other words, I like my environment. Where you work, I'm convinced, makes a big difference. Not everyone can make it in special education long enough or be lucky enough to find that right place. Thank goodness I did.

Source: A beginning teacher. Email communication June 21, 2001. 
assistance that beginning teachers need at the time they need it (Huling-Austin, 1987). The primary strategy for induction has been to offer some form of structured assistance and support to first-year teachers to ease their transition from university student to effective teacher. Mentoring of the first-year teacher by an experienced, competent teacher has developed as a favored option for providing this support (Little, 1990). Theresa Bey (1990) listed three primary reasons for mentoring programs:

1. To help beginning teachers cope with "dissatisfactions, disappointments and difficulties" (p. 51) of the first year of teaching

2. To combat high turnover and to reduce attrition

3. To improve teacher performance.

Klug and Salzman (1991) also found that beginning teachers preferred structured programs as opposed to unstructured programs. Wildman, Magliaro, Niles, and Niles (1992) cautioned, however, that "mentoring programs should not attempt to rigidly specify mentoring roles" (p. 205). They suggested that mentoring programs will be beneficial when they do not seek to rigidly specify the roles and responsibilities of the mentor but, rather, tailor the assistance to the specific needs of the beginning teacher. Huling-Austin, Putman, and Galvez-Hjornevik (1986) have recommended a middle-ofthe-road approach with enough flexible structure to accommodate the emerging needs of the participants. They added that

\footnotetext{
a prepackaged, "canned" program determined in advance will not be flexible enough to meet the variety of needs that are likely to emerge. ... It is important to closely monitor the specific emerging needs and concerns of participants and to select appropriate interventions accordingly. (pp. $52-53)$
}

Thus, it seems that it is important to have clear goals for mentoring programs and a flexible structure that allows the mentor to tailor the assistance to the specific individual needs of the beginning teacher. Huling-Austin (1990a) concluded that there is no magic formula for mentoring. She referred to mentoring as "squishy business" (p. 48), in which the mentor must vary the role to meet the needs of beginning teachers. The benefits of mentoring identified in the research seem to focus on the support provided to first-year teachers, their perception that mentoring has helped them be better teachers, the increased satisfaction with the job that, it is hoped will lead to a lower rate of attrition, and greater willingness to ask for assistance and support.

\section{RECOMMENDATIONS FOR SUPPORTING BEGINNING SPECIAL EDUCATION TEACHERS}

Given what we know about the needs and concerns of beginning special education teachers and the importance of the early years of teaching, additional supports clearly should be provided to these young professionals. A successful first-year experience is a critical factor in retaining special education teachers (Billingsley, 1993; Bogenschild, Lauritzen, \& Metzke, 1988; Harris and Associates, 1991; Smith-Davis \& Cohen, 1989). To encourage more support for beginning special education teachers, the Council for Exceptional Children (CEC) adopted standards for special educators who are entering professional practice; these standards include a minimum of a 1-year mentorship beginning the first year of professional special education practice (Council for Exceptional Children, 1996). CEC (1998) identified five purposes of a mentorship program for special educators:

1. To facilitate the application of knowledge and skills

2. To convey advanced knowledge and skills

3. To assist timely acculturation to the school climate

4. To reduce stress and enhance job satisfaction

5. To support professional induction.

White and Mason (2000) further offer the following guidelines for a mentoring program for special educators.

1. The objectives of the Mentoring Program, its purposes, and options are clear and have been agreed upon by beginning teachers, experienced mentors, and representatives from the district and building level administrators.

2. Information concerning roles, expectations, policies, provisions, and desired outcomes of the Mentoring Program is readily available and shared with beginning teachers, mentors, and administrators.

3. The Mentoring Program is planned and adequately funded.

4. All first year teachers are expected to participate in the mentoring program.

5. Mentoring for special education teachers may be coordinated with other, more general, mentoring programs within the school district, but must specifically address those issues unique to special education.

6. The Mentoring Program is designed to provide assistance and support only and is not related to any formal evaluations, certification requirements, or reemployment issues. (p. 6)

Effective mentoring has been found to be correlated with both job satisfaction and improved retention of beginning special education teachers (Whitaker, 2000a) and thus has emerged as a favorite form of support. 


\section{The Role of the Mentor and Other Special Education Teachers}

I conducted a series of focus groups, two surveys, and a series of interviews with beginning special education teachers and their mentors to examine the needs and concerns of beginning special education teachers and the supports that seem to be needed. Beginning special education teachers identified other special education teachers and their assigned mentors as the individuals who provided the most support and assistance to them (Whitaker, in press).

Several studies have found that the mentor for a beginning special education teacher is perceived as more effective if the mentor is also a special education teacher (Whitaker, 2000a; White, 1995). To be effective, mentoring must be provided on a consistent basis with contact between the mentor and protégé occurring at least weekly (Whitaker, 2000a). Thus, mentors must be willing to dedicate a significant amount of time to the mentoring process.

The beginning special education teachers reported that the informal unscheduled meetings were the most frequently provided method of support and also were the most effective form of support. They did report needing longer scheduled meetings periodically to deal with more complex issues such as developing the first IEP or discussing specific students (Whitaker, 2000a). They reported that they needed opportunities to observe other teachers and to be observed. Many beginning special education teachers, however, were not given these opportunities. When they were, they found them very helpful (Whitaker, 2000a). Boyer and Gillespie (2000) stress that support at the classroom level is most important for new special education teachers and that what happens inside the classroom is a critical factor in supporting teachers and retaining them.

Given this information, mentors and other special education teachers can be most helpful to beginning special education teachers by:

1. Stopping by to check on the beginning special education teacher at least weekly (and preferably several times per week). These visits need not be long but should afford opportunities for the beginning teacher to ask questions and for the more experienced teacher to answer questions and reassure and encourage the beginning teacher.

2. Scheduling longer meetings at least once a month to address issues of concern to the beginning teacher. Concerns might be developing a behavior management plan, writing the first IEP, or planning an instructional unit. Some of the concerns require more time and more planning for the more experienced teacher to be of much assistance. These are issues that cannot be dealt with effectively "on the fly" and require uninterrupted time for both teachers. Finding the time is often a challenge when the teachers do not share the same planning period. Sometimes the meetings can be held before or after school, over lunch, or when another staff member can occasionally cover a class for one of the teachers.

3. Introducing the new teacher to staff members and orienting him or her to the new school. A tour of the school is helpful to the new teacher. Where are the staff restrooms, the library, the copy machines? Novice teachers also appreciate being introduced to key staff members - the principal, assistant principal, guidance counselor, psychologist, secretary, custodian, librarian, and other teachers and paraprofessionals. Including the new teacher at lunch and making sure that he or she is not sitting alone at faculty meetings are good ways of reducing the isolation that beginning special education teachers often feel.

4. Arranging for the beginning special education teacher to observe other, more experienced teachers and then sitting down and discussing what was observed and what the teacher learned from the observation. Observations are most effective if the teacher has time to discuss the observation afterward. Focused observations are often particularly helpful. For example, if the beginning teacher reports having difficulty with getting students into the room and started on their work, the opportunity to observe an experienced teacher handle this aspect of the school day may be appropriate and probably would require only a 15 -minute observation.

5. Observing the beginning special education teacher and providing feedback. The teachers need to know what they are doing right as well as areas in which they could improve. Often the observations can concentrate on a specific area of concern identified by the beginning teacher. Also important are follow-up discussions, in which the more experienced teacher helps the beginning teacher analyze his or her own lessons and learn from the discussions.

6. Providing assistance with special education policies, procedures, and paperwork. This is the area in which the beginning special education teachers reported needing the most assistance and in which they reported the greatest discrepancy between the amount of assistance needed and the amount received. Certainly special education is replete with 
paperwork and procedural requirements. These aspects of the job often are overwhelming to the novice teacher. The more experienced special education teacher can be of great assistance by providing samples of completed forms, answering questions regarding the procedures and forms, assisting the novice in completing the paperwork, and modeling how to follow the required procedures. Too often the beginning special education teachers report being left to "sink or swim," and while some manage to swim, too many sink in the process.

Fellow special education teachers can share their organizational strategies for managing the paperwork burden and for making sure that procedures are followed. They can check up on the beginners periodically and reassure them that they are "doing it right." The beginning teachers feel a tremendous responsibility to follow all of the procedures and get the paperwork completed correctly but often are completely confused regarding how to accomplish this goal.

7. Orienting the beginning special education teacher to the school and district and to the school policies and procedures. Beginning special education teachers report being confused by the school's written and unwritten rules. Each school has its own policies and procedures-how to get supplies, how to refer a child for counseling, from whom to get textbooks, how many copies can be run on the copier, whether parents are allowed to observe in classes, how to schedule a field trip, which teachers work well with which types of students, and so on. Although most veteran teachers no longer worry about these issues, they remain critical for the beginning teacher.

8. Introducing the teacher to available materials and other resources. Beginning special education teachers report being overwhelmed by trying to find appropriate materials for the diverse population of students they serve. In some cases the teachers do not have much in terms of readily available materials. These teachers struggle to make everything that they use in the classroom. Other teachers report having closets and shelves full of materials but not knowing where to start to select the most appropriate materials for certain students.

The experienced teacher can be helpful in suggesting a limited number of good materials with which the novice teacher can become familiar and use initially with the students. Then, as the beginning teacher becomes comfortable with those materials and indicates a need for additional resources, the experienced teacher can refer the teacher to other materials or other sources for materials. Introducing materials over time avoids the potential problem of overwhelming the novice teacher with too much too soon.

9. Consulting with the beginning special education teacher regarding discipline - both in terms of overall classroom management and with individual students. The way the school year begins is crucial to the success of the novice teacher. Thus, a more experienced special education teacher can help by sitting down with the beginner and helping him or her develop a classroom discipline plan. The two can jointly develop classroom rules and consequences and have those posted for the first day or plan to have the teacher and students jointly develop the rules and consequences the first day. They also can plan procedures and routines for the students for entering the classroom, getting started on their work, asking for assistance, going to the restroom, and leaving the classroom at the end of the period or end of the day. The teacher then can proceed to teaching the rules, procedures, and routines during the first week. This helps the teacher know what to do with the students from the first day and helps to assure a smooth beginning of the school year.

As the school year progresses, the beginning teacher typically struggles with discipline, particularly with certain students. Often the novice teacher is afraid to admit that he or she cannot handle a certain student for fear of appearing incompetent. Colleagues need to watch for signs that the novice teacher is struggling with discipline and reassure the novice that this is normal and that all teachers are challenged by some students and their behaviors.

Once the teacher has been reassured, it is easier to sit down and begin to brainstorm strategies for intervening with the behavior. Beginning special education teachers report that the assistance they were given with discipline was not particularly helpful. This may reflect the difficulty in assisting someone else with behavior management or may reflect the lack of expertise of the teachers providing the assistance. At times the novice teacher may have to be referred to the psychologist, an administrator, or other professional who may be able to provide additional assistance with specific students. 
10. Assisting the beginning special education teacher with scheduling, planning, and organization and management systems. Colleges rarely are able to fully prepare special education teachers for the challenge of developing a schedule, planning units and lessons, and managing the large amounts of paperwork that special education generates. Experienced teachers develop shortcuts and systems for getting these tasks done efficiently, but beginning special education teachers report spending long hours trying to get everything done. Several teachers might share their "secrets" with the new teacher so he or she can pick and choose from the various systems and develop one that will work best for him or her.

11. Consulting with the novice teacher regarding curriculum and instruction. Beginning special education teachers report feeling overwhelmed by the task of developing their own curriculum and finding the appropriate instructional methods for so many different students with so many different learning styles who are working at so many different levels. In most special education programs the teachers cannot just plan to go to the next chapter in the textbook. Although this is not an area on which most first-year special education teachers are ready to focus, they did report needing quite a bit more assistance than they received.

Based on studies of teacher development, this is an area that beginning teachers are more ready to tackle during their second year. For this reason, support should not stop after the firșt year of teaching. Certainly, issues of curriculum and instruction are important and should be addressed. As the novice teacher moves through the first year, the mentor or more experienced special education teacher can begin to encourage more discussion of issues related to curriculum and specific instructional strategies. Initially these discussions may be directed more at whole-class concerns, but by the end of the first year or during the second year, they should shift to individual students.

12. Providing encouragement and support. There is no more critical role than just being there for the beginning teacher to provide a shoulder on which to cry, a partner with whom to share successes, and a sounding board on which to try out new ideas. The number one need identified by beginning special education teachers was emotional support. The job is difficult-especially for beginners. Most of these young teachers want to do a good job and need to hear that they are doing well and are making a difference with the students. They need that reassurance. They also need to hear that all lessons don't go perfectly even for the most experienced teacher, and that it is all right when a lesson doesn't go well. And they need to learn to celebrate their successes and to learn from their mistakes. Finally, they need to hear that eventually the job does get at least a little bit easier.

\section{The Role of the Administrator}

Although the mentor or other special education teachers play the most significant roles in providing support to beginning special education teachers, perceived lack of support from administrators is one of the reasons most frequently cited for special education teachers leaving the classroom (Billingsley \& Cross, 1991; Karge \& Freiberg, 1992; Westling \& Whitten, 1996). Thus, the role of the administrators is critical in supporting beginning special education teachers. Administrators can be most helpful to beginning special education teachers by:

1. Assigning a good experienced special education teacher as a mentor to the novice special education teacher. Research has shown that the best mentor for a special education teacher is another special education teacher who teaches students with the same disabilities and who is perceived as approachable, trustworthy, supportive, enthusiastic, and comfortable working with other teachers and who has good communication skills in addition to strong professional knowledge (Whitaker, 2000a). The mentors selected have to be willing to devote a significant amount of time to the mentoring — checking with the teacher at least once a week and meeting more formally at least once a month. One of the most important steps an administrator can take to support beginning special education teachers is to assign them good mentors.

2. Arranging time for the mentors or other special education teachers to work with the beginning special education teacher. Mentoring is perceived as significantly more effective if the mentor and protégé have the same planning period at least once a week (Whitaker, 2000a). Administrators can arrange for the two teachers to have the same planning period, or they can arrange for time to be made available periodically by providing substitutes or other teachers to periodically cover their classes. Administrators also can make sure that mentors and their protégés are not 
overburdened with additional duties such as bus duty or hall duty so they can meet briefly during those times as well.

\section{Providing staff development for the mentors. Men-} tors are more likely to be effective if they know what is expected of them as mentors and what the firstyear special education teachers are likely to need from them. Administrators might provide a workshop for the mentors that covers (a) the role of the mentor, (b) needs of beginning teachers in general and of beginning special education teachers specifically, (c) strategies for providing assistance, (d) techniques for observing and conferencing, and (e) a suggested schedule of mentoring activities. Many resources are available for mentors and beginning special education teachers. Some of these are listed at the end of this article.

4. Arranging observations of other teachers. Just as other special education teachers can assist in arranging observations, administrators can assist in selecting teachers to observe and making arrangements so the novice teacher is free to make the observations.

\section{Observing the beginning special education teacher} and providing feedback. Because the first year of teaching is stressful for most teachers, it may be best if other teachers make the first observations and provide feedback. These initial observations may assist the beginning teacher in becoming more comfortable with the observation process. By the end of the first month, the administrator(s) should begin doing walk-through observations to get a feel for how things are going for the teacher and to begin to identify areas in which assistance may be needed. These walk-through observations should be followed by more formal observations.

Feedback should be given after the observations, as the beginning teacher will want to know what the administrator thinks and recommends. The administrator should note positive aspects of the observation and then focus on one area for assistance, which ideally should be decided through joint discussions with the administrator, beginning teacher, and mentor. These observations should be positive, and the administrator should provide encouragement and assistance rather than be evaluative or punitive with the novice teacher, who is just beginning to learn the profession.
6. Planning district level induction activities. Districtlevel administrators should plan district-wide induction activities for all beginning teachers-explaining the mission and philosophy of the district, presenting the expectations for the teachers, explaining policies and procedures, introducing district support staff, explaining payroll and benefits packages, and generally welcoming and orienting the new teachers to the school district. In addition, the special education administrator should present an orientation to special education, presenting the expectations for special education teachers; explaining special education policies, procedures, and paperwork; introducing special education support staff; explaining how to get needed supplies and materials; and again generally welcoming and orienting the teachers to the special education department.

Beginning teachers are so overwhelmed during the first few weeks of school that these orientation meetings should be held prior to the opening of the school year. Certainly, paying a stipend for attending is nice, but most beginning special education teachers indicate that they would be happy to attend without pay just to get the needed assistance.

7. Providing a handbook of policies, procedures, and forms. School districts should provide a general district employee handbook of policies and procedures and should review this with all beginning teachers. In addition, each school should have a teacher handbook that includes school policies and procedures. A school administrator should ensure that the beginning special education teacher has a copy of the school handbook and should review the contents with the teacher and answer any questions.

Finally, the special education department should have a handbook of policies and procedures and sample forms. Beginning special education teachers report that such a handbook is a lifesaver. With it, they should be able to refer to procedures as they are needed and to see samples of completed forms as they fill out those forms for their own students.

8. Making the demands placed on the beginning special education teacher reasonable. Too often, beginning teachers are placed in the most difficult teaching assignments: They often have the most difficult students, the largest caseloads, and the most preparations each day (Glickman, 1990; Gordon, 1991). In addition, $25-30 \%$ of beginning special education are placed in positions in which they find themselves 
teaching students they are not certified to teach (Boe, Cook, Bobbitt, \& Terhanian, 1998; Whitaker, 2000a). Clearly this situation is not in the best interest of the students or the teacher. Administrators can help by placing beginning special education teachers in positions for which they are prepared and in which they can be successful. Administrators should keep the caseloads reasonable and limit the number of extra duties these teachers have to manage during their first year.

9. Making the needed resources available. Administrators can assist beginning special education teachers by making sure that they have adequate classroom space, access to needed equipment, the necessary supplies in their classrooms, and an adequate supply of materials to use with their students. Administrators also need to be sure that beginning special education teachers know what resources are available in the district (audiovisual equipment, instructional materials resource centers, etc.) and how to order needed materials and supplies.

10. Including the beginning special education teacher and making him or her feel a part of the school. Beginning special education teachers talk a lot about feeling isolated (Whitaker, 2000b). Because they often are not part of a grade level or a department, they tend to be excluded. It is disheartening when teachers are given $\$ 200$ for supplies but the special education teacher is not included ... or when memos go out and the special education teacher is forgotten . . . or when materials are ordered for classroom teachers and the special education teacher is told that nothing was ordered for special education. Administrators can show their support by being more cognizant of including the beginning special education teacher (and, indeed, all special education teachers) in whatever transpires at the school.

11. Supporting the beginning special education teacher in his or her dealings with other staff, parents, and students. Beginning special education teachers may need assistance in negotiating their roles with other teachers, in gaining faculty support, and in securing the necessary supports for their students. Administrators can help by showing their faith in the skills of the beginning teacher and making clear the expectation that the school staff will work with the new teacher in the best interests of the students.

Beginning teachers sometimes are intimidated by parents and may want the administrator present for certain meetings in which conflict is expected.
Administrators should make clear to the novice special education teacher that they are available as needed to assist with these meetings.

Finally, beginning special education teachers may need support and assistance with certain students. Administrators again should make clear that they are there to assist and will help the novice teacher in working with these difficult and challenging students - and then should make every effort to provide that assistance themselves or to access other support personnel to assist. Because beginning teachers are often hesitant to ask for help, the administrator must be observant and offer help when it seems to be needed.

12. Providing encouragement and support. All teachers need to hear occasional words of encouragement and support from their administration, and this is even more critical for novice special education teachers who are just beginning to define themselves as teachers. They need to hear that they are appreciated, that their efforts are noticed, and that the administration is aware of their hard work. They need to have their positive accomplishments recognized. Administrators can do much to help the beginning special education teacher retain his or her sense of efficacy, thereby promoting student achievement as well as increasing the likelihood that the novice teacher will remain in the field.

\section{The Role of the College or University Professor}

College and university professors also have a role in supporting beginning special education teachers (Boyer and Gillespie, 2000). Certainly the education they provide should be a support to the beginning teacher when he or she begins teaching. Traditionally, however, colleges and universities have viewed their role as complete when a student graduates. Perhaps it is time to reexamine that position. The novice special educators often have had fairly close relationships with professors and are accustomed to going to those professors for encouragement and advice. Must that relationship end with graduation? College and university professors can be most helpful to beginning special education teachers by:

1. Adequately preparing them for their first year of teaching. Beginning teachers who feel that they have been adequately prepared are more likely to remain in the field, particularly if their field-based experiences were perceived as positive (Brownell \& Smith, 1992; Brownell, Smith, McNellis, \& Lenk, 1994-95). Many beginning teachers report feeling 
inadequately prepared for the challenges they faced during their first year of teaching.

Providing more practical experiences to preservice teachers and putting more emphasis on real-life problem-solving seem to promote transfer of learning from the college classroom to the first teaching assignment. In addition, special education faculty at the college and university level need to be aware of the areas in which beginning special education teachers require the most assistance so the faculty can revise the curriculum to provide additional preparation in those areas wherever possible.

2. Helping the preservice teacher develop a more realistic view of the first year of teaching. Many preservice teachers enter the profession with an unrealistic view of their own expertise and of the challenges they will face. Although we do not want to dampen their enthusiasm, they need to be better prepared for the "reality shock" of the classroom. Activities such as interviewing a first-year teacher or reading some of the accounts of the first year of teaching (see the Resources at the end of this article) would be helpful in preparing these teachers for the shock of that first year.

3. Encouraging the preservice teachers to ask questions and seek assistance and support. Beginning teachers tend to hesitate to ask for assistance for fear of appearing incompetent. College and university instructors can work to develop a supportive atmosphere in which students feel comfortable asking questions and asking for assistance. They then can encourage (and even require) the preservice teachers to ask questions and seek assistance from a variety of sources during their field experiences to establish the habit of consultation and collaboration.

4. Continuing to be available to the first-year special education teachers. At the beginning of the school year, first-year teachers have not yet gotten to know or feel comfortable with the district staff. If their professors can continue to be available through visits, telephone calls, on-line discussion groups, and e-mail, the beginning special educator has someone to whom to turn even in those early days and even if little support is provided at the school or district level. This aspect of support is particularly critical for beginning teachers who teach students with low-incidence disabilities and those who teach in small, rural school districts that may not have other, more experienced professionals to whom to turn for assistance.
5. Following up with graduates during their first year to learn how the graduates are doing and what they, as professors, could have done to better prepare the novice teachers. Asking beginning special education teachers what components of their preservice education were most beneficial and what components were insufficient will enable the college and university staff to make their programs even more effective in the future.

6. Offering graduate courses that prepare experienced teachers to be mentors. Many school districts are too small to have enough special education teachers to fill a graduate course. And few school districts have staff members who are qualified to teach a graduate level course on mentoring. And yet, mentoring is a new role for most teachers - a role that requires good professional development for the mentor to understand and perform adequately in the role.

\section{FINAL THOUGHTS}

The amount and perceived effectiveness of support provided to beginning special education teachers correlates with job satisfaction and with retention in the field (Whitaker, 2000a). And certainly any assistance and support provided to these novice teachers should improve their effectiveness as teachers (Council for Exceptional Children, 1998). Even though the mantra "It takes a village to raise a child" is frequently repeated and generally accepted, there is less acceptance of the need for the whole village to support the teacher, and especially the beginning special education teacher. With the current shortage of special education teachers, we all need to do whatever we can to support our beginning teachers, help them become the best teachers they can be, and increase the chances of retaining them in the field.

\section{REFERENCES}

Bey, T. M. (1990). A new knowledge base for an old practice. In T. M. Bey \& C. T. Holmes, (Eds.), Mentoring: Developing successful new teachers, Reston, VA: Association of Teacher Educators. (ERIC Document Reproduction Service No. ED 322 118)

Billingsley, B. S. (1993). Teacher retention and attrition in special and general education: A critical review of the literature. Journal of Special Education, 27, 137-174.

Billingsley, B. S., \& Cross, L. H. (1991). Teachers' decisions to transfer from special to general education. Journal of Special Education, 24, 496-511. 
Boe, E. E., Cook, L. H., Bobbitt, S. A., \& Terhanian, G. (1998). The shortage of fully certified teachers in special and general education. Teacher Education \& Special Education, 21, 1-21.

Bogenschild, E. G., Lauritzen, P., \& Metzke, L. (1988). A study of teacher attrition. Information on personnel supply and demand. (ERIC Document Reproduction Service No. ED 311 614)

Boyer, L. \& Gillespie, P. (2000). Keeping the committed: The importance of induction and support programs for new special education teachers. Teaching Exceptional Children, 33(1), 10-15.

Brownell, M. T., \& Smith, S. W. (1992). Attrition/retention of special education teachers: Critique of current research and recommendations for retention efforts. Teacher Education \& Special Education, 15, 229-248.

Brownell, M. T., Smith, S. W., McNellis, J., \& Lenk, L. (1994-95). Career decisions in special education: Current and former teachers' personal views. Exceptionality, 5, 83-102.

Cheney, C. O., Krajewski, J., \& Combs, M. (1992). Understanding the first year teacher: Implications for induction programs. Teacher Education \& Special Education 15(1), 18-24.

Cooke, B. L., \& Pang, K. C. (1991). Recent research on beginning teachers: Studies of trained and untrained novices. Teaching \& Teacher Education, 7(1), 93-110.

Corcoran, E. (1981). Transition Shock: The beginning teacher's paradox. Journal of Teacher Education, 32(3), 19-23.

Council for Exceptional Children (1996). What every special educator must know: The international standards for the preparation and certification of special education teachers, ( $2 \mathrm{~d}$ ed.). Reston, VA: Council for Exceptional Children.

Council for Exceptional Children (1998). What every special educator must know: The international standards for the preparation and licensure of special educators. (3rd ed.). Reston, VA: The Council for Exceptional Children.

Council for Exceptional Children (2000). Bright Futures for exceptional learners: An action agenda to achieve quality conditions for teaching and learning [On-line]. Available: Http://www.cec.sped. org/spotlight/cond/bf_intro.html

Cross, L. H., \& Billingsley, B. S. (1994). Testing a model of special educator's intent to stay in teaching. Exceptional Children, 60, $411-412$.

Darling-Hammond, L. (1985). Valuing teachers: The making of a profession. Teachers College Record, 87, 205-218.

Dollase, R. H. (1992). Voices of beginning teachers: Visions and realities. New York: Teacher's College Press.

Gaede, O. F. (1978). Reality shock: A problem among first year teachers. Clearing House, 51, 405-409.

Glickman, C. D. (1990). Preface. In T. M. Bey \& C. T. Holmes (Eds.), Mentoring: Developing successful new teachers. Reston, VA: Association of Teacher Educators.

Gordon, S. P. (1991). How to help beginning teachers succeed. Alexandria, VA: Association for Supervision \& Curriculum Development.

Glidewell, J. C., Tucker, S, Todt, M., \& Cox, S. (1983). Professional support systems: The teaching profession. In A. Nadler, J. Fisher, \& B. DePaulo (Eds.), New directions in helping: Vol. 3. Applied perspective on help-seeking and receiving (pp. 182-212). New York: Academic Press.

Harris, L., \& Associates, Inc. (1991). The Metropolitan Life survey of the American teacher, 1991: The first year: New teacher's expectations and ideals. New York: Metropolitan Life Insurance Company. (ERIC Document Reproduction Service No. ED 354 224)

Harris, L. \& Associates, Inc. (1992). The Metropolitan Life survey of the American teacher, 1991: The second year: New teacher's expectations and ideals. New York: Metropolitan Life Insurance Company. (ERIC Document Reproduction Service No. ED 354 226)

Hirsh, S. A. (1990). Designing induction programs with the beginning teacher in mind. Journal of Staff Development, 11(4), 24-26.

Huling-Austin, L. (1986). What can and cannot reasonably be expected from teacher induction programs? Journal of Teacher Education, $37(1), 2-5$.

Huling-Austin, L. (1987). Teacher induction. In D. M. Brooks (Ed.), Teacher induction: A new beginning_(pp. 3-24). Reston, VA: Association of Teacher Educators.

Huling-Austin, L. (1990a). Mentoring is squishy business. In T. Bey \& C. T. Holmes (Eds.), Mentoring: Developing successful new teachers (pp. 39-50). Reston, VA: Association of Teacher Educators.

Huling-Austin, L. (1990b). Teacher induction programs and internships. In W.R. Houston (Ed.), Handbook of research on teacher education. New York: Macmillan.

Huling-Austin, L., \& Murphy, S. C. (1987, April). Assessing the impact of teacher induction programs: Implications for program development. Paper presented at annual meeting of American Educational Research Association, Washington, DC. (ERIC Document Reproduction Service No. ED 283 779)

Huling-Austin, L., Putman, S., \& Galvez-Hjornevik, C. (1985). Model teacher induction project study findings. Final report. Austin: University of Texas Research and Development Center for Teacher Education. (ERIC Document Reproduction Service No. ED 270 442)

Karge, B. D., \& Freiberg, M. R. (1992, April). Beginning special education teachers: At risk for attrition. Paper presented at annual meeting of American Educational Research Association, San Francisco. (ERIC Document Reproduction Service No. ED 353 235)

Kirby, S. \& Grissmer, D. W. (1993). Teacher attrition: Theory, evidence, and suggested policy options. Santa Monica, CA: Rand Corporation. (ERIC Documentation Reproduction Service No. ED 364533 )

Klug, B. J. \& Salzman, S. A. (1991). Formal induction vs. informal mentoring: Comparative effects and outcomes. Teaching \& Teacher Education, 7, 241-251.

Kuzmic, J. (1994). A beginning teacher's search for meaning: Teacher socialization, organizational literacy, and empowerment. Teaching \& Teacher Education, 10(1), 15-27.

Little, J. W. (1990). The mentor phenomenon and the social organization of teaching. In C. B. Cazden (Ed.), Review of research in education (Vol. 16, pp. 297-351). Washington, DC: American Educational Research Association.

Lortie, D. C. (1975). Schoolteacher: A sociological study. Chicago: University of Chicago Press.

McKnab, P. (1983). Special education personnel attrition in Kansas, 1976 to 1982: A summary of attrition rates and an analysis of reasons for quitting. Office of Special Education and Rehabilitative Services, Division of Personnel Preparation. Washington, DC. (ERIC Document Reproduction Service No. ED 238 231) 
McLaughlin, M. W. Pfeifer, R. S., Swanson-Owens, D., \& Yee, S. (1986). Why teachers won't teach. Phi Delta Kappan, 67, 420-426.

Miller, M. D., Brownell, M. T., \& Smith, S. W. (1999). Factors that predict teachers staying in, leaving, or transferring from the special education classroom. Exceptional Children, 65, 201-218.

Moran, S. W. (1990). Schools and the beginning teacher. Phi Delta Kappan, 72, 210-213.

National Association of State Boards of Education. (2000, April). Teacher induction programs. Policy Update, 8(5).

Odell, S. J. (1986). Induction support of new teachers: A functional approach. Journal of Teacher Education, 37(1), 26-29.

Odell, S .J. (1989a). Characteristics of beginning teachers in an induction context. In J. Reinhartz (Ed.), Teacher induction (pp. 42-51). Washington, DC: National Education Association.

Odell, S. J. (1989b). Developing support programs for beginning teachers: Assisting the beginning teacher (pp. 19-38). Reston, VA: Association of Teacher Educators.

Odell, S. J. (1990). Mentor teacher programs: What research says to the teacher. Washington, DC: National Education Association. (ERIC Document Reproduction Service No. ED 323 185)

Odell, S. J., \& Ferraro, D. P. (1992). Teacher mentoring and teacher retention. Journal of Teacher Education, 43, 200-204.

Recruiting New Teachers. (1999). Learning the ropes: Urban teacher induction programs and practices in the United States. Belmont, MA.

Ryan, K. (Ed.). (1992). The roller coaster year: New York: HarperCollins.

Schlechty, P. C. \& Vance, V. S. (1983). Recruitment, selection, and retention: The shape of the teaching force. Elementary School Journal, 83, 469-487.

Singer, J. D. (1992). Are special educator's career paths special? Results from a 13-year longitudinal study. Exceptional Children, 59, 262-279.

Smith-Davis, J. \& Cohen, M. (1989). Preventing attrition through teacher induction and mentoring [and] entry-year induction programs and practices: A bibliography. Information on supply and demand. (ERIC Document Reproduction Service No. ED 314 923)

Tonnsen, S., \& Patterson, S. (1992). Fighting first-year jitters. Executive Educator, 14(1), 29-30.

Veenman, S. (1984). Perceived problems of beginning teachers. Review of Educational Research, 54, 143-178.

Weinstein, C. S. (1988). Preservice teachers' expectations about the first year of teaching. Teaching \& Teacher Education, 4, 31-40.

Westling, D. L. \& Whitten, T. M. (1996). Rural special education teachers' plans to continue or leave their teaching positions. Exceptional Children, 62, 319-335.

Whitaker, S. D. (1999). Induction-year special education teachers: Perceptions of mentoring and its relationship to attrition. Unpublished doctoral dissertation, University of South Carolina, Columbia.

Whitaker, S. D. (2000a). Mentoring beginning special education teachers and the relationship to attrition. Exceptional Children, 66, 546-566.

Whitaker, S. D. (2000b). What do first-year special education need? Teaching Exceptional Children, 33(1), 28-36.
Whitaker, S. D. (in press). Needs of beginning special education teachers: Implications for teacher education. Teacher Education \& Special Education.

White, M. (1995). Factors contributing to special education teacher attrition: How a one year internship affects the attrition rates of special education teachers in Kentucky. Unpublished doctoral dissertation, Vanderbilt University, Nashville, TN.

White, M., \& Mason, C. (2000, June 26). Mentoring induction principles and guidelines (draft). Reston, VA: Council for Exceptional Children.

Wildman, T. M., Magliaro, S. G., Niles, R. A., \& Niles, J. A. (1992). Teacher mentoring: An analysis of roles, activities, and conditions. Journal of Teacher Education, 43, 205-213.

Woolfolk, A., Rusoff, B., \& Hoy, W. (1990). Teachers' sense of efficacy and their beliefs about managing students. Teaching \& Teacher Education, 6, 137-148.

\section{RESOURCES FOR MENTORS}

Bey, T. M., \& Holmes, C. T. (Eds.), (1992). Mentoring: Contemporary principles and issues. Reston, VA: Association of Teacher Educators.

Boyer, L., \& Gillespie, P. (2000). Keeping the committed: The importance of induction and support programs for new special education teachers. Teaching Exceptional Children, 33(1), 10-15.

Conderman, G., \& Stephens, J. T. (2000). Voices from the field: Reflections from beginning special educators. Teaching Exceptional Children, 33(1), 16-21.

Feiman-Nemser, S. (1996). Teacher mentoring: A critical review. (ERIC Document Reproduction Service No. ED 397 060)

Littleton, M., Tally-Foos, K., \& Wolaver, R. (1992). Mentoring: A support system for new teachers. The Clearing House, 65(3), 172-174.

Mateja, J. (1992). Mentoring: The possibility that became a reality. Intervention in School \& Clinic, 27, 298-302.

Rowley, J. B. (1999, May). The good mentor. Educational Leadership, 56(8), 20-22.

Shaughnessy, M. F., \& Siegel, J. (1997). The first-year special education teacher: Their desperate need for mentors. B.C. Journal of Special Education, 21(1), 73-80.

Weeks, P. V. (1992). A mentor's point of view. Intervention in School \& Clinic, 27(5), 303-306.

Whitaker, S. D. (2000). What do first-year special education need? Teaching Exceptional Children, 33(1), 28-36.

\section{RESOURCES FOR BEGINNING SPECIAL EDUCATION TEACHERS}

Cohen, M. K., Gale, M., \& Meyer, J. M. (1994). Survival guide for the first-year special education teacher (Rev. ed.). Reston, VA: Council for Exceptional Children.

Maroney, S. A. (2000). What's good? Suggested resources for beginning special education teachers. Teaching Exceptional Children, 33(1), 22-27.

McCaffrey, M. E. (2000). My first year of learning: Advice from a new educator. Teaching Exceptional Children, 33(1), 4-8. 
Shelton, C. F., \& Polingue, A. B. (2000). The exceptional teacher's handbook: The first-year special education teacher's guide for success._Thousand Oaks, CA: Corwin Press.

Wong, H. K., \& Wong, R. T. (1998). The first days of school: How to be an effective teacher ( $2 \mathrm{~d}$ ed.). Mountain View, CA: Harry K. Wong Publications.

\section{WEBSITES}

Ohio Department of Education http://edhd.bgsu.edu/MentorNet

Teacher.Net Mentor Center http://teachers.net/mentors/
Teacher Mentoring http://coled.mankato.msus.edu/dept/labdist/mentor/

ASCD Mentoring Resources http://www.mentors.net/

Best Practices in Mentoring http://www.teachermentors.com

Teachers Helping Teachers http://www.pacificnet.net/ mandel

National Clearinghouse for Professions in Sp. Ed. http://www.special-ed-careers.org/pdf/retguide.pdf

Teachers Network for New Teachers http://www.teachnet.org/docs/ntol/ 


\section{COLLABORATIVE
PRACITIONERS
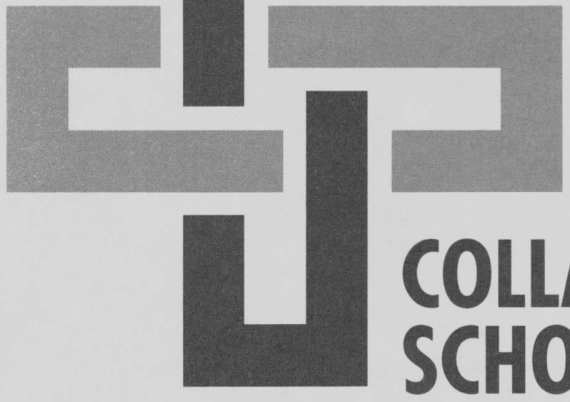 \\ COLLABORATIVE SCHOOLS}

Second Edition

Marleen C. Pugach

University of Wisconsin, Milwaukee
Lawrence J. Johnson

University of Cincinnati

This latest revision has a strong focus on teamwork and includes new material on reconceptualizing collaboration and team-based problem-solving.

The authors give us a powerful vision of schools as learning communities, not just for students, but also for adults, teachers, parents, and school administrators. This new edition has been expanded to include interagency connections and ways to develop partnerships with schools. The school-family collaboration chapter covers cross-cultural situations and gives practical strategies. Much more emphasis is given to diversity in this revision.

You'll find proven activities and checklists at the end of each chapter. Problem-solving, team teaching, and working with supporting groups are all part of this new edition. IDEA updates are included throughout the book.

\section{SPECIAL FEATURES}

- Covers basic skills to facilitate communication.

- Includes numerous activities to experience collaboration.

- Teaches strong, effective teamwork skills.

- Focuses on schools as learning communities. 


\section{Focuson Exceptional children}

\section{Professional update}

Learning Disabilities Association of America International Conference

February 13-16, 2002

Denver, Colorado

Contact: LDA

4156 Library Road

Pittsburgh, PA 15234

\section{Midwest Symposium for}

Leadership Behavior Disorders

February 21-22, 2002

Hyatt Regency-Crown Center

Kansas City, Missouri

Contact: 913-492-8755 Fax: 913-492-2546

\section{Council for Exceptional Children}

April 3-6,-2002

New York, New York

Contact: www.cec.sped.org

800-486-5773

American Educational Research Association

April 1-5, 2002

New Orleans, Louisiana

Contact: www.aera.net

202-223-9485 